аргументовано висловлювати власні думки, розширювати професійну лексику та вміння відповідного освітньо-кваліфікаційного рівня.

Звертаючись до застосування описаного вище методу case-study, варто зауважити, що впровадження лише case study як безальтернативної форми навчання у процес проведення практичних занять 3 психологічних дисциплін не є методично правильним, тому необхідно застосовувати й інші методи та форми навчання в їхньому органічному поєднанні. Варто пам'ятати, що ефективність використання case study залежить від майстерного його поєднання 3 традиційними методами навчання. Було 6 методичною помилкою намагатися побудувати весь курс практичних занять з психологічних дисципліни лише на основі розгляду конкретних ситуацій. Мистецтво навчання в сучасних умовах передбачає використання різних методів та технологій, тому доцільно виділяти на вивчення конкретних ситуацій в середньому 25-30\% від часового розподілу практичного заняття.

Висновки. Таким чином, проаналізувавши необхідність застосування кейсметоду на практичних заняттях $з$ психологічних дисциплін для студентів-психологів, можемо прийти до висновку, що використанням методу конкретних ситуацій підвищує ефективність засвоєння навчального матеріалу. Подальших досліджень потребує конкретизація основних етапів роботи над кейсами 3 конкретно визначених дисциплін психологічного спрямування.

\title{
Література
}

1. Пащенко Т. Кейс-метод як сучасна технологія навчання спеціальних дисциплін / Т. Пащенко // Молодь і ринок. - 2015. - № 8. - С. 94-99.

References

1. Pashhenko T. Kejs-metod yak suchasna texnologiya navchannya special'ny'x dy'scy'plin / T. Pashhenko // Molod’ i ry’nok. - 2015. - \# 8. - S. 94-99.

Одержано статтю: 4.10 .2018

Прийнято до друку: 18.10.2018

УДК :373.2.011.3-51

DOI:10.15330/esu.14.126-134

\author{
Тетяна Танько, \\ доктор педагогічних наук, професор, \\ Харківський національний педагогічний \\ університет імені Г.С.Сковороди \\ (м. Харків, Україна) \\ Tetiana Tanko, \\ Doctor of pedagogical sciences, Professor, \\ H.S. Skovoroda Kharkiv National Pedagogical \\ University (Kharkiv, Ukraine) \\ faculty-pre-school@hnpu.edu.ua
}

\section{ТЕОРЕТИЧНІ АСПЕКТИ ФОРМУВАННЯ ПРОФЕСІЙНО-ЗНАЧУЩИХ ЯКОСТЕЙ ОСОБИСТОСТІ ВЧИТЕЛЯ, ВИХОВАТЕЛЯ ЗАКЛАДУ ДОШКІЛЬНОЇ ОСВІТИ}

\author{
THEORETICAL ASPECTS OF FORMING PROFESSIONALLY IMPORTANT \\ QUALITIES OF THE PERSONALITY OF TEACHER AS AN EDUCATOR OF \\ PRESCHOOL EDUCATIONAL INSTITUTION
}

У статті висвітлено значущість професійно-значуиих якостей особистості вчителя, вихователя закладу дошкільної освіти, розкрито погляди вітчизняних педагогів минулого та сучасності на особливості їх формування. Наголочено, що якості особистості педагога є творчим компонентом педагогічної майстерності, яка містить у собі мобільність і орихінальність мислення; вміння враховувати мінливість прочесу 
навчання, корегувати свої дії під впливом обставин, що змінюються, враховувати конкретні умови і співвідносити з ними рімення, ио приймаються; емочійна чутливість. Підкреслено роль впливу вихователя закладу доикільної освіти на дітей, ио передбачас врахування двох його аспектів: функиіонального та особистісного, які існують в єдності. Визначено вимоги до якостей особистості, психолого-педагогічної і спечіальної підготовки вихователя закладу доикільної освіти.

Ключові слова: вчитель, вихователь, педагог, заклад доикільної освіти, педагогічна майстерність, професійно-значуці якості.

The article highlights the importance of a professional qualities of the teacher-educator's personality for the institution of preschool education, reveals the views of the Ukrainian teachers of the past and the present on the peculiarities of their formation. it is emphasized that the qualities of the teacher's personality are a creative component of pedagogical skill, which includes mobility and originality of thinking; the ability to take into account the variability of the learning process, adjust their actions under the influence of changing circumstances, take into account the specific conditions and correlate with them the decisions to be taken; emotional sensitivity. Relying on the teacher's professional profile, emphasis is placed on such professional qualities as love for the child, justice, pedagogical insight and observation, pedagogical cycle, pedagogical imagination, sociability, demanding, perseverance, purposefulness, organizational ability, balance and endurance, professional ability, as well as initiative, perseverance, quality of the organizer and leader, flexibility of behavior, understanding of students, balance, selfconfidence, ability to make a new job, comp entnist. The role of the teacher of the institution of preschool education for children, which involves taking into account two of its aspects of functional and personal, which exist in unity, is emphasized. The requirements for the qualities of the educator's personality, psychological-pedagogical and special preparation are defined: the qualities defining the ideological orientation of the individual: the combination of a high ideological level with principality, awareness of social duty and civic responsibility, the qualities that determine the professional-pedagogical orientation - loving children and humane attitude to them, observation, goodwill, sincerity, justice, cheerfulness, balance, sense of humor; qualities that determine cognitive orientation - continuous improvement of their skills on the basis of pedagogical science and modern practice; Requirements for psychological and pedagogical preparation: knowledge of child psychology, anatomy and physiology of the child, peculiarities of physical development, general and preschool pedagogy, literature and art, pedagogical process; the volume and composition of special training, practical skills in various techniques.

Key words: teacher, educator, institution of preschool education, pedagogical skill, professional qualities.

\section{Постановка проблеми у загальному вигляді та ії зв'язок з важливими науковими та практичними завданнями}

Особистість педагога завжди була предметом помітної уваги видатних педагогів і психологів, які відбивали в своїх наукових концепціях погляди і думки стосовно існування людини, iii ролі у суспільному житті, вихованні підростаючого покоління.

Сучасна дидактика приділяє особливу увагу проблемі формування індивідуально-неповторній особистості 3 iі мотивами, потребами, інтересами i якостями. Головним завданням навчання визначається не механічне накопичення суми знань, а вдосконалення особистості, розвиток ії професійно-значущих якостей.

Разом $з$ цим слід відзначити, що педагогічна наука приділяє недостатню увагу питанням формування професійно значущих якостей особистості, обмежуючись, в основному, декларацісю їх безсумнівної важливості. Особистість майбутнього вчителя, вихователя розглядається у психолого-педагогічній літературі як складна 
динамічна структура, що адекватно відбиває структуру педагогічної діяльності, але до нашого часу у дослідженні навчально-виховного процесу велика увага приділялася об'єктивним, переважно зовнішнім умовам, а досліджень, присвячених вивченню внутрішнього світу студентів, внутрішніх умов удосконалення підготовки майбутнього педагога, проведено досить мало. Саме тому зберігають актуальність дослідження педагогічних закономірностей формування професійних якостей особистості педагога, виявлення педагогічних умов їх ефективного застосування.

Аналіз останніх досліджень i публікацій, в яких започатковано розв'язання порушеної проблеми і на які спирається автор

Біля витоків розробки наукових засад формування професійно-значущих якостей вчителя, вихователя, підготовки його до педагогічної діяльності стояли такі видатні зарубіжні та вітчизняні педагоги, як А. Ф Дістервег, М. О. Добролюбов, К. Д. Ушинський, Я. А. Коменський, І. Г. Песталоцці, М. Х. Свєнтицька, А. С. Симонович, Л. М. Толстой, Є. І. Тихєєва, М. Г. Чернишевський, Л. К. Шлегер, та інші.

Слід відзначити, що у працях і висловах прогресивних мислителів минулого прослідковується розуміння того, що ефект від педагогічної діяльності можливий лише тоді, коли вчитель має не тільки грунтовні знання, а й певні професійно значущі якості.

Найбільш актуальні дослідження у галузі підготовки педагогічних кадрів до професійної діяльності, формування їхніх професійно-значущих якостей пов'язані 3 іменами таких відомих психологів і педагогів, як Н. І. Болдирев, Ф. Н. Гоноболін, І. А. Зязюн, Н. В. Кузьміна, Л. В. Кондрашова, В. І. Лозова, О. Г. Мороз, І. Т. Огородников, Г. В. Троцко, Р. І. Хмелюк, О. І. Щербаков, та інших, які вивчали якості особистості педагога, його здібності, структуру діяльності, професійну майстерність.

Певний внесок у вирішення проблеми підготовки вихователів закладів дошкільної освіти, формування їхніх професійно-значущих особистісних якостей внесли Є. А. Гребенщикова, Е. Ю. Демурова, А. В. Запорожець, А. Б. Миколаєва, Т. А. Рєпіна, Л. Г. Семушина, А. П. Усова, та інші.

Формулювання цілей статті (постановка завдання)

Метою даної статті $є$ простеження теоретичних ідей вітчизняних педагогів шодо значення та формування професійно значущих якостей вчителя, вихователя закладу дошкільної освіти.

Виклад основного матеріалу дослідження 3 повним обгрунтуванням одержаних наукових результатів

Особистість учителя, його здібності й особистісні якості, знаходились в центрі уваги багатьох вітчизняних педагогів. Так, М. Г. Чернишевський у своїй праці “Нариси політичної економіі” звертав увагу на педагогічну діяльність, яка маючи деякі зовнішні загальні риси з іншими видами праці, відрізняється від них тим, що кінцевий іiі продукт “не предмет, сторонній людині, а сама людина, цією працею задовольняються потреби зовсім іншого роду, ніж потреби в будинках чи стільцях, в чоботах чи сорочках" [8, с. 549]. Значну увагу він приділяв особистісним якостям учителя, вихователя, вважаючи, що сформувати ті чи інші якості учнів може лише педагог, який сам їх має. М. Г. Чернишевський підкреслював, що “вихователь сам повинен бути тим, чим він хоче зробити вихованця" [8, с. 445]. Причину небажання навчатися, неуважність і неуспішність учнів він вбачав в учителеві, його неумінні знаходити потрібні прийоми викладання.

М. О. Добролюбов вважав, що учитель, який володіє великим об'ємом знань та педагогічних умінь, потрібними особистісними якостями, любовно та уважно 
ставиться до дітей, швидко завоює авторитет серед учнів. На думку М. А. Добролюбова, це має велике значення в педагогічній справі.

Вплив особистості вихователя на молоду душу, зазначав К. Д. Ушинський, складає ту виховну силу, яку не можна замінити ні підручниками, ні моральними сетенціями, ні системою покарань та заохочень. Багато, звісно, значить дух навчального закладу, але цей дух живе не в стінах, не на папері, а в характері більшості вихователів і звідти вже переходить у характер вихованців. [6, с. 13, 14].

Любов до педагогічної праці та учнів, цю найважливішу якість учителя виділяє Л. М. Толстой, який гостро критикував тих учителів, що не поважають особистість дитини і намагаються якомога швидше виховати іiі відповідно до суспільного ідеалу. Л. М. Толстой наголошував, що справжній учитель буде лише 3 того, хто поєднує в собі і любов до справи, і до учнів.

Значну увагу особі учителя приділяв Я. Ф. Чепіга. Він підкреслював, що “для справжнього учителя не досить здобути досконалість у методичних способах, бути гарним методистом: йому потрібно досягти певної духовної висоти моральних переконань. Яка ціна його педагогічним знанням, коли він п’яниця, шахрай, взагалі нечесна, груба людина? Уміння навчити не $\epsilon$ кінцевим ідеалом учителя. Мало передати самі сухі, мертві знання,- треба прищепити дитині, що $є$ найліпшого в людині, вкласти в неї свою високу душу" [7, с. 4]. Він вимагав від учителя виховання у собі необхідних, на його думку, особистісних якостей. Я. Ф. Чепіга писав, що "чесна незаплямована праця педагога вимагає в нас таких чеснот, як справедливість, доброта, терпіння, любов. Вони покажуть учителеві певні шляхи - як досягти цілей і завдань справжньої педагогіки. Виховання їх в нас освітить наше життя сяйвом найвищого ідеалу й дасть сили пронести увесь тягар учителювання радісно і несхибно" [7, с. 8].

Значну роль у розвитку педагогічної думки відіграв А. С. Макаренко, який розробив програму виховання особистості. Під метою виховання він розумів програму людської особистості, програму характеру людини, причому в поняття характеру він вкладав увесь зміст особистості, тобто і характер зовнішніх проявів і внутрішнього переконання, і політичне виховання і знання - усю картину людської особистості.

Психологічні аспекти педагогічної праці розкриваються у роботах Ф. Н. Гоноболіна, який одним із перших у повоєнний період звернувася до вивчення особистості вчителя. Вирішальним фактором успіху педагогічної роботи $\epsilon$ особистість учителя в цілому, в усьому складному розмаітті їі психологічних рис, писав Ф. Н. Гоноболін у своїй відомій “Книзі про вчителя".

Як вважав Ф. Н. Гоноболін, “...люди не народжуються обдарованими педагогами, а стають ними, причому цей шлях становлення $є$ досить довгим, починається нерідко ще з юнацьких літ і триває в учителя 3 великим педагогічним стажем" [1, с. 117].

Прогрес у вивченні закономірностей формування особистості педагога значною мірою зумовлений дослідженнями Н. В. Кузьміної та О. І. Щербакова.

У працях Н. В. Кузьміної розглядається процес формування особистості вчителя, розвитку його педагогічних здібностей i майстерності. Визначивши структуру педагогічної діяльності, Н. В. Кузьміна простежує механізм і послідовність розвитку професійно важливих якостей вчителя у системі його підготовки і в перші роки самостійної роботи. Під педагогічними здібностями, на думку вченого, слід розуміти ансамбль властивостей особистості, що відповідає 
вимогам педагогічної діяльності і забезпечує легке оволодіння цієї діяльності і досягнення в ній високих показників.

Заслуговує на увагу психологічне дослідження О. І. Щербакова з проблеми формування особистості вчителя. Педагогічна майстерність, - на його думку, - це синтез особистих рис учителя, його знань, умінь $\mathrm{i}$ навичок. Формування майстерності учителя органічно пов'язане з вихованням його особистості.

В. О. Сластьонін, спираючись на проект професіограми, відокремлює такі професійні якості як любов до дитини, справедливість, педагогічна проникливість i спостережливість, педагогічний такт, педагогічна уява, товариськість, вимогливість, наполегливість, цілеспрямованість, організаційні здібності, врівноваженість і витримка, професійна працездатність.

В. І. Гинецинський відокремлює дві групи якостей вчителя: 3 одного боку, товариськість і емоційна контактність, висока пластичність поведінки (експресивні здібності); емоційна чутливість (імпресивні здібності); з іншого - достатньо високий рівень емоційної стабільності, розсудливості, толерантності до емоційних конфліктних ситуацій.

P. I. Хмелюк до факторів придатності до педагогічної діяльності відносить: інтерес до професії вчителя, бажання працювати у цій галузі, наявність елементарних знань, умінь, навичок, необхідних для оволодіння спеціальністю тощо.

Великого значення надає якостям особистості учителя Л. В. Кондрашова. На іiі думку, учителю необхідно володіти “не тільки об'ємом професійних знань, але і такими особистісними якостями, які забезпечують успішність виконання професійних функцій” [2, с. 3]. До них, на думку Л. В. Кондрашової, належать: моральні переконання, педагогічні здібності, професійна пам'ять, схильність, інтереси, працездатність, педагогічна спрямованість, психічна витривалість, емоційність, моральний потенціал особистості, тобто ії ставлення до проявів, подій 3 огляду на моральні суспільні норми та вимоги щодо вихованості учителя. Л. В. Кондрашова підкреслює, що розвинуті інтелектуальні якості особистості майбутнього вчителя сприяють засвоєнню сутності процесу професійного становлення, формуванню готовності студентів до педагогічної діяльності.

Ю. М. Кулюткін виділяє десять професійно значущих якостей особистості вчителя. До них він відносить такі, як ініціативність, наполегливість, якості організатора i керівника, гнучкість поведінки, розуміння учнів, врівноваженість, впевненість у собі, вміння вносити нове у працю, компетентність.

Ю. К. Бабанський відзначає такі якості особистості вчителя, які є творчим компонентом педагогічної майстерності: мобільність і оригінальність мислення; вміння враховувати мінливість процесу навчання, корегувати свої дії під впливом обставин, що змінюються, враховувати конкретні умови і співвідносити 3 ними рішення, що приймаються; емоційна чутливість.

Важливу роль емоційних якостей особистості у поєднанні 3 вольовими підкреслює О. В. Барабанщиков.

Звичайно, список перелічених вище якостей особистості, кожна 3 яких видається важливою 3 професійної точки зору, може бути продовженим. Багато 3 них співвідносні з основними компонентами структури педагогічної діяльності.

Основою для комплексного дослідження професійно значущих якостей особистості вчителя може слугувати динамічна функціональна структура особистості, запропонована К. К. Платоновим. Ця структура містить у собі чотири підструктури. 
Перша, соціально-обумовлена підструктура, відбиває спрямованість особистості, iіi інтереси, ідеали, світогляд, ставлення до праці. навички.

Друга характеризує навченість, включає добутий досвід, знання, вміння,

Можливості навченості особистості визначаються розвитком іiі третьої підструктури, що включає окремі психічні процеси - мислення, увагу, пам'ять, уявлення, емоції, волю - і відповідні їм якості особистості.

Біологічно зумовлені якості особистості становлять четверту підструктуру (темперамент, інстинкти, задатки тощо).

Професія вихователя дошкільної установи також висуває великі вимоги до особистісних якостей майбутнього спеціаліста. Першу спробу визначити основні вимоги, що повинні висуватися до професії і особистості вихователя було зроблено у 30-ті роки Ф. С. Левін-Шириною та Л. В. Менжерицькою:

- вихователь повинен бути патріотом своєї батьківщини;

- бути майстром своєї справи, любити дітей, знати їх особливості й вивчати дітей. Володіти методикою педагогічної роботи, постійно підвищувати свою кваліфікацію;

- цікавитись літературою, мистецтвом. Знати музику, живопис, художню літературу;

- бути організатором, мати витримку, сильний характер, бути життєрадісним, мати культурні навички. [4, с. 304].

Так, Є. А. Гребенщикова підкреслюючи активну роль вихователя, виділяє вимоги до його особистості: ідейність, суспільно-політичну активність, педагогічну майстерність. Ідейність вихователя, зазначає $\mathrm{C}$. А. Гребенщикова, органічно поєднана 3 його активною участю у суспільно-політичному житті держави.

У дослідженні А. Б. Миколаєвої розглянуто психологічні особливості впливу особистості вихователя дитячого садка на дошкільників. Як вона зауважує у своїй роботі, найбільш значущими для дітей-дошкільників виступають комплекси якостей, що характеризують зовнішні особливості поведінки вихователя й емоційно-оцінні прояви ставлення до дошкільників. У зв'язку з цим вона рекомендує вихователю враховувати загальний фон і ефекти його стосунків з дитиною, вигадуючи різного роду виховні прийоми педагогічної роботи.

Особистість вихователя дитячого садка вперше розглядається у дослідженні А. Б. Миколаєвої у світлі психологічної теорії колективу та особистості. Її дослідження розкриває специфіку та індивідуальну своєрідність особистісного впливу вихователя на дошкільників.

Експериментальне дослідження, проведене А. Б. Миколаєвою довело, що для дітей - вихователь дитячого садка - це людина, яка втілює у собі всю сутність поняття “дорослий”. Складна природа впливу вихователя на дітей передбачає врахування двох його аспектів: функціонального й особистісного, які існують в єдності, але саме персональні особливості впливу вихователя надають йому в очах дитини індивідуальну своєрідність.

Л. Н. Башлакова також дослідила вплив спілкування вихователя 3 дошкільниками на взаємостосунки дітей.

У цілому вимоги до якостей особистості вихователя, психолого-педагогічної і спеціальної його підготовки можна об'єднати у такі групи: 
- якості, що визначають ідейну спрямованість особистості: поєднання високого ідейного рівня 3 принциповістю, усвідомлення суспільного обов'язку i громадянської відповідальності;

- якості, що визначають професійно-педагогічну спрямованість - любов до дітей $\mathrm{i}$ гуманне ставлення до них, спостережливість, педагогічний такт, доброзичливість, щирість, справедливість, життєрадісність, рівновага, почуття гумору;

- якості, що визначають пізнавальну спрямованість - постійне удосконалення своєї майстерності на засадах педагогічної науки і сучасної практики;

- вимоги, що висуваються до психолого-педагогічної підготовки: знання дитячої психології, анатомії і фізіології дитини, особливостей фізичного розвитку, загальної і дошкільної педагогіки, літератури і мистецтва, педагогічного процесу; - об’єм і склад спеціальної підготовки, практичні вміння в різноманітних методиках.

Майбутнім вихователям повинні бути властиві також такі професійноособистісні якості, які визначають формування емоційно-вольового і пізнавального аспекту їх особистості. Ці особистісні якості, що характеризують педагога, входять до третьої підструктури (за К. К. Платоновим). У той же час професійно значущі якості особистості, пов'язані з увагою, пам'яттю, уявленням, мисленням, емоціями, вольовими процесами сприяють підвищенню ефективності навчання майбутніх вихователів.

До важливих компонентів майстерності вихователя закладу дошкільної освіти дослідники відносять й педагогічні здібності: артистичні, художні, музичні та інші, що сприяють більш оригінальному і творчому вирішенню педагогічних завдань лише при достатньо високому рівні розвитку педагогічних здібностей взагалі.

Спеціальні педагогічні здібності виявляються у динаміці творчої діяльності вчителя-вихователя, в перебудові цієї діяльності (а іноді і самої особистості) відповідно до реалізації цілей педагогічної системи та аналізу реакції дітей.

До педагогічних відносять, у першу чергу, здібності, що відповідають окремим компонентам педагогічної діяльності: гностичні, конструктивні, організаційні, комунікативні. Таким чином, педагогічні здібності відображають структуру педагогічної діяльності, будучи у той же час передумовою іiї успішного здійснення.

Саме загальнопедагогічні здібності становлять основу оволодіння педагогом професійної майстерності. Безумовно, “ансамбль" засобів, що сприяють ефективному формуванню педагогічної майстерності, включає, крім педагогічних здібностей, велику кількість інших професійно-важливих характеристик. Вони зумовлені розвитком як спеціальних здібностей, які відбивають специфічні особливості предмета, так і загальнозначущих якостей особистості.

Аналіз спостережень за діяльністю майбутніх вихователів, зокрема музичних керівників у реальних умовах дошкільної установи (під час роботи) дає підставу стверджувати, що у певної частини студентів, які володіють навичками і вміннями гри на музичних інструментах на достатньо професійному рівні, виявляються нерозвиненими загальнопедагогічні компоненти основ музично-педагогічної майстерності. Крім того, студентам не завжди вдається достатньо професійно використовувати різні сполучення музично-виконавської і музично-просвітницької діяльності.

Застосовуючи музично-виконавські навички i вміння, частина майбутніх вихователів-музичних керівників зазнають труднощів у використанні живої, яскравої i, разом з тим, доступної для дітей дошкільного віку мови, не вміють аргументовано i 
педагогічно доцільно ілюструвати свою педагогічну дію власним виконанням музичних творів.

Педагогічна праця вимагає розвитку як загальних, так $\mathrm{i}$ спеціальних здібностей. Тому ефективність діяльності вихователя, музичного керівника багато в чому залежить від того, якою мірою гармонійно поєднуються в його особистості здібності: загальні, педагогічні і музичні. Доцільно в цьому зв'язку зупинитися на деяких положеннях теорії здібностей, пов'язаних 3 питаннями взаємозв'язку їх загальних і спеціальних компонентів, 3 питаннями залежності здібностей від особливостей психічних процесів (емоцій, волі, уваги, пам'яті тощо).

Здібності людини - це, передусім, здібності до праці, до навчання. Розглядаючи проблему взаємовідношення загальних і спеціальних здібностей, учені вказують на їх тісну залежність, на вияв загальної обдарованості у розвитку спеціальних здібностей. Вони підкреслюють взаємозв'язок здібностей з розвитком психічних процесів: мисленням, сприйняттям тощо. На думку вчених, розвиток людини у першу чергу зумовлений розвитком його здібностей, а не оволодінням знаннями, вміннями і навичками. Так, С. Л. Рубінштейн наполягав на "наступності" між “родовими” здібностями, притаманними всім людям (пам'яттю, мисленням, емоційністю), і здібностями, за якими люди відрізняються один від одного. "Всі спеціальні здібності людини - це врешті решт різноманітні вияви, сторони загальних iii здібностей до навчання і праці". [5, с. 643].

Діалектична єдність загального, особливого й одиничного дозволяє визначити у здібностях не тільки те, що диференціює людей, але й те, що їх поєднує.

Здібності - це ансамбль засобів, котрі необхідні для успішного здійснення будь-якої діяльності, вони формуються у конкретній діяльності i поза нею не існують.

Як загальні здібності слід розглядати ті, які можуть слугувати загальними умовами успішної діяльності людини в різноманітних їі формах. Ці особливості пов”язані з “родовими” якостями людини, уявленням, емоційністю, волею, пам'яттю тощо. Спеціальні здібності уможливлюють досягнення високих результатів у певних спеціальних галузях діяльності, наприклад, літературній, образотворчій, музичній, сценічній тощо. До спеціальних здібностей слід віднести і такі, які реалізуються у практичній діяльності, зокрема, в педагогічній.

Висновки представленого у статті дослідження і перспективи подальших наукових розвідок із зазначеного напряму

Таким чином стрижневими якостями особистості вчителя, вихователя закладу дошкільної освіти є педагогічні здібності й педагогічна майстерність, які не можуть бути ізольовані від його загального розвитку. Професійно-педагогічні якості являють собою сукупність соціальних і психічних якостей педагога, котрі забезпечують успіх у навчанні і вихованні, становлять основу майстерності вчителя, вихователя, яка визначається як синтез наукових знань, умінь, навичок, методичного мистецтва та особистісних якостей.

Література

1. Гоноболин Ф.Н. Книга об учителе. - М., 1965, 260с.

2. Кондрашова Л. В. Теоретические основы воспитания нравственно-психологической готовности студентов пед. института к профессиональной деятельности: автореф. дис....д-ра. пед. наук: - /Л.В. Кондрашова. - М., 1989. - 36 с.

3. Кузьмина Н. В., Кухарев Н. В. Психологическая структура деятельности учителя. - Гомель, 1976. $-34 \mathrm{c}$. 
4. Левин-Ширина Ф.С., Менжерицкая Д. В. Дошкольное воспитание. - 2-е изд. Перераб. И доп., М. Укризд., 1939. - 304 с.

5. Рубинштейн С. Л. Основы общей психологии. - М.: Учпедгиз, 1946. - 643 с.

6. Ушинский К. Д. Собр.соч. - С.-Петербург, 1975. - 624 с.

7. Чепіга Я. Ф. Самовиховання вчителя. - 2-е вид., К., 1917. - 31 с.

8. Чернышевский Н. Г. Очерки политической экономии: Полн.собр.соч. - Т.9. - М.: ГИХЛ, 1949. - C. $455-459$

\section{References}

1. Honobolyn F.N. Knyha ob uchytele.- M., 1965, 260s.

2. Kondrashova L. V. Teoretycheskye osnovy vospytanyia nravstvenno-psykholohycheskoi hotovnosty studentov ped. ynstytuta $\mathrm{k}$ professyonalnoi deiatelnosty: avtoref. dys...d-ra. ped. nauk: /L.V. Kondrashova. - M., 1989. - 36 s.

3. Kuzmyna N. V., Kukharev N. V. Psykholohycheskaia struktura deiatelnosty uchytelia. - Homel, 1976. $-34 \mathrm{~s}$.

4. Levyn-Shyryna F.S., Menzherytskaia D. V. Doshkolnoe vospytanye. - 2-e yzd. Pererab. Y dop., M. Ukryzd., 1939. - $304 \mathrm{~s}$.

5. Rubynshtein S. L. Osnovy obshchei psykholohyy. - M.: Uchpedhyz, 1946. $-643 \mathrm{~s}$.

6. Ushynskyi K. D. Sobr.soch. - S.-Peterburh, 1975. - 624 s.

7. Chepiha Ya. F. Samovykhovannia vchytelia. - 2-e vyd., K., 1917. - $31 \mathrm{~s}$.

8. Chernyshevskyi N. H. Ocherky polytycheskoi ekonomyy: Poln.sobr.soch. - T.9. - M.: HYKhL, 1949.S. 455-459.

Одержано статтю: 1.10 .2018

Прийнято до друку: 30.10 .2018 